\title{
Study on the Preparation of Nanosized Titanium Dioxide with Tubular Structure by Hydrothermal Method and Their Photocatalytic Activity
}

\author{
Yu-Zhen Zeng, Yu-Chang Liu, Yun-Fang Lu, and Jen-Chieh Chung
}

\begin{abstract}
In this study, we attempt to synthesize nanosized titanium dioxide with tubular structure for the photocatalytic applications, and self-prepared anatase $\mathrm{TiO}_{2}$ powder is the precursor. We demonstrated that nanosized $\mathrm{TiO}_{2}$ with tubular structure could be synthesized with a $\mathrm{NaOH}$ hydrothermal treatment on $\mathrm{TiO}_{2}$ powder and then with a subsequent acid washing. Furthermore different formation mechanism of nanotubes could be got by controlling the $\mathrm{pH}$ value of acid washing step. In this research, we investigate the influence of different $\mathrm{pH}$ values of acid washing on the crystalline-structure, optical absorption range, porosity, specific surface area, and photo-catalytic activity of nanotubes. The influence of the preparation methods on crystalline-structure of photocatalysts and activities of photocatalytic reaction are obvious. The experimental results show that anatase $\mathrm{TiO}_{2}$ nanotubes are produced as the $\mathrm{pH}$ value of acid washing is decreased to 1.3. Under this condition, the outer diameter and length of the nanotube is about $10 \mathrm{~nm}$ and $1 \mu \mathrm{m}$ respectively, its group is like petals. And it possesses the largest surface area of $381.2 \mathrm{~m}^{2} / \mathrm{g}$, band gap of $3.12 \mathrm{eV}$ and the best photocatalytic activity.
\end{abstract}

Index Terms -Anatase, hydrothermal method, photocatalytic activity, titanium dioxide nanotube.

\section{INTRODUCTION}

Titanium dioxide $\left(\mathrm{TiO}_{2}\right)$ has been widely employed in paint, coating, and filler because of its high stability, simple preparation, and non-toxicity. It's also a kind of semiconductor for such applications as optoelectronic device, sensor and alloy materials. And $\mathrm{TiO}_{2}$ has excellent photocatalytic properties. In 1972, Fujishima and Honda [1] succeeded for the first time, in the photoelectrochemical decomposition of water under visible light irradiation with n-type $\mathrm{TiO}_{2}$ as the anode and without any applied electric power. It has drawn much attention, and numerous efforts have been synthesized nanosize $\mathrm{TiO}_{2}$ because of its photocatalytic properties. $\mathrm{TiO}_{2}$ had also been fabricated into nanopowders, films, mesoporous $\mathrm{TiO}_{2}$ with different methods Recently, much researchers devoted to the synthesis of nanotubes with large specific surface areas and their structure were demonstrated as $\mathrm{Na}_{2} \mathrm{Ti}_{2} \mathrm{O}_{4}(\mathrm{OH})_{2}$ [2], [3], $\mathrm{H}_{2} \mathrm{Ti}_{3} \mathrm{O}_{7}$. $0.8 \mathrm{H}_{2} \mathrm{O}$ [4], $\mathrm{H}_{2} \mathrm{Ti}_{4} \mathrm{O}_{9} \cdot \mathrm{H}_{2} \mathrm{O}$ [5], lepidocrocite titanates [6], [7], etc.

Manuscript received November 24, 2013; revised January 7, 2014. This work was supported in part by the National Science Council, Executive Yuan of Taiwan.

The authors are with the Chemical Engineering Division, Institute of Nuclear Energy Research, Taoyuan County 32546, Taiwan, R.O.C. (e-mail: yzzeng@iner.gov.tw, eddyliu@iner.gov.tw, yflu@iner.gov.tw, yflu@iner.gov.tw ).
Nanotubes with the diameter of $8 \sim 10 \mathrm{~nm}$ and length of $10 \sim 1000 \mathrm{~nm}$ were produced by alkali reaction for $24 \sim 72 \mathrm{~h}$ [8]. Not only titanium, Oxygen atom but also hydrogen was discovered from the EDX analysis, and its chemical formula was considered as $\mathrm{H}_{2} \mathrm{Ti}_{n} \mathrm{O}_{2 \mathrm{n}+1}$, structure as anatase-rutile phase. Seo et al. [9] reported that the amount and length of nanotubes was proportional to the reaction temperature. The largest amount of nanotubes was manufactured at $200^{\circ} \mathrm{C}$. It possessed the length of $200-250 \mathrm{~nm}$, surface area of $270 \mathrm{~m}^{2} / \mathrm{g}$. Tsai et al. [10] had prepared $\mathrm{TiO}_{2}$ nanotubes with hydrothermal method. The variation of the surface area, diameter, and pore size of nanotubes was investigated by controlling the temperature from 110 to $150^{\circ} \mathrm{C}$. A model of lamellar to tubular structure was proposed for the formation mechanism of $\mathrm{TiO}_{2}$ nanotubes after acid rinsing.

In this study, we demonstrated that $\mathrm{TiO}_{2}$ nanotubes could be synthesized with a $\mathrm{NaOH}$ hydrothermal treatment on self-prepared anatase $\mathrm{TiO}_{2}$ powders. And the effects on structure, specific surface area, and photocatalytic activity for $\mathrm{KI}$ of $\mathrm{TiO}_{2}$ nanotubes were investigated by adjusting different $\mathrm{pH}$ values during the acid rinsing process.

\section{MATERIALS AND METHODS}

\section{A. Experiment}

The precursor used for nanotube production was self-prepared anatase $\mathrm{TiO}_{2}$ powder, which was synthesized from titanium ethoxide by sol-gel method. And the approach for manufacturing $\mathrm{TiO}_{2}$ nanotubes was processed with hydrothermal method in autoclave. The preparation was initiated by treating self-prepared anatase $\mathrm{TiO}_{2}$ powder with strong base such as a $\mathrm{NaOH}$ solution into a Teflon-lined stainless autoclave at $110^{\circ} \mathrm{C}$ for $20 \mathrm{~h}$. The process was similar to those reports [11], except that the present treatment was conducted hydrothermally, rather than under atmospheric pressure. After this treatment and subsequent cooling, the paste in the bottom layer of Teflon was taken out to $\mathrm{pH}$-value regulation by titrating with $\mathrm{HCl}$ solution. The final products were obtained by washing with DI water and subsequent drying.

\section{B. Characterization of Titanium Dioxide Nanotube}

The phase identification of those samples from different synthesis processes was conducted with $\mathrm{X}$-ray diffraction (XRD) using a SIEMENS D8 diffractometer equipped with $\mathrm{CuK}_{\alpha}$ radiation. The data were collected for scattering angles (20) rangine from 20 to $80^{\circ}$ with a step size of $0.02^{\circ}$. The 
porosity was characterized by $\mathrm{N}_{2}$ adsorption at $77 \mathrm{~K}$ using Micromeritics ASAP2020. And the specific surface area of the nanotube was determined from the Brunauer-Emmett-Teller (BET) equation. The UV-VIS spectrophotometer (Thermo, Eolution 600) was employed to determine the absorbance of light for the photocatalystic powders. The microstructures were explored with a scanning electron microscope (SEM, Hitachi S-4800). The photocatalytic activity was evaluated through the formation of $\mathrm{I}_{3}{ }^{-}$due to oxidation of $\mathrm{I}^{-}$to $\mathrm{I}_{2}$ as a model reaction. Photocatalytic reaction is based on the following reaction.

$$
\begin{aligned}
& \mathrm{KI} \rightarrow \mathrm{K}^{+}+\mathrm{I}^{-} \\
& \mathrm{I}^{-}+\mathrm{I}^{-} \rightarrow \mathrm{I}_{2} \\
& \mathrm{I}_{2}+\mathrm{I}^{-} \rightarrow \mathrm{I}_{3}^{-}
\end{aligned}
$$

A reaction system was set up by adding $1 \mathrm{~g}$ of catalyst powder into $100 \mathrm{ml}, 0.2 \mathrm{M} \mathrm{KI}$ aqueous solution in a beaker. And this reactant was irradiated with UV light $(500 \mathrm{~W})$ at room terperature with constant stirring speed. At regular time intervals, the suspension was extracted and filtered. The concentration of liberated $\mathrm{I}_{3}{ }^{-}$ions in the clear supernatant was monitored by determining the absorbance at 350nm from an UV-Vis spectrophotometer. The result of absorbance was introduced into the Beer-Lambert's Law. Then the formation profiles of $\mathrm{I}_{3}{ }^{-}$in the suspension of the nanotubes prepared at different formation $\mathrm{pH}$ value can be obtained as a function of UV irradiation time.

$$
A=\varepsilon b c
$$

\section{A: absorbance}

$\varepsilon$ : absorptivity coefficient of the solute (26303 $\mathrm{dm}^{3} / \mathrm{cm} \cdot \mathrm{mol}$ )

$b$ : path length of light $(1 \mathrm{~cm})$

$c$ : concentration of the solute

\section{RESULTS AND DISCUSSION}

In this study, we attempted to synthesize anatase $\mathrm{TiO}_{2}$ nanotubes by hydrothermal method with lower temperature. The powders withdrawn after the reaction were titrated with acid at different $\mathrm{pH}$ value of $0.8,1.3,2.2,4$, and 6.5, respectively. Lin [12] reported that $\mathrm{TiO}_{2}$ powders used as the provider of raw material were corroded by strong acid, and the formation mechanism of nanotubes were in a dissolutionprecipitation-growing procedure. However, Wang et al. [13] and T. Kasuga et al. [14] discussed that during treatment with $\mathrm{NaOH}$ solution, some Ti-O bonds of the $\mathrm{TiO}_{2}$ precursor were broken, leading to the formation of lamellar fragments that were the intermediate phase in the formation process of the nanotubes material. The tubular structure was achieved by rolling slowly after the acidic post-treatment process, and therefore the acid rinsing step had become very important during the $\mathrm{TiO}_{2}$ nanotubes formation process.

Crystalline structure is one of the key factors for photocatalytic activity of semiconductor photocatalysts. Fig. 1 shows the XRD patterns taken from initial $\mathrm{TiO}_{2}$ (precursor) and photocatalysts with $\mathrm{HCl}$ washing to different $\mathrm{pH}$ values.
This fact indicates that the precursor of reaction is $\mathrm{TiO}_{2}$ with anatase crystalline-phase the same as the reference of JCPDS 21-1272. In the $\mathrm{pH}$-decreasing course with $\mathrm{HCl}$ washing of $\mathrm{pH}=6.5$, there are characteristic peaks positioned at $2 \theta=24^{\circ}$ and $28^{\circ}$. These peaks have been assigned to the diffraction of titanates such as $\mathrm{Na}_{2} \mathrm{Ti}_{2} \mathrm{O}_{5} \cdot 5 \mathrm{H}_{2} \mathrm{O}, \mathrm{Na}_{2} \mathrm{Ti}_{3} \mathrm{O}_{7}$, lepidocrocite titanates. The amount of $\mathrm{H}^{+}$ions provided from the acid may not be enough to replace the $\mathrm{Na}^{+}$, therefore the formation catalytic powders are still the structure with titanate not titanium dioxide.



Fig. 1. XRD patterns (a). Standard $\mathrm{TiO}_{2}$ with crystal structure of anatase from JCPDS 12-1272. (b). Initial $\mathrm{TiO}_{2}$ and photocatalysts prepared from hydrothermal $\mathrm{NaOH}$ treatment, followed by acid rinsing under different $\mathrm{pH}$ values.

With the decrease in $\mathrm{pH}$ to 4 and 2.2, there appears to be a corresponding decrease in the intensity of the $28^{\circ}$ peak relative to that of $24^{\circ}$. This has been ascribed to the decrease in the $\mathrm{Na}: \mathrm{H}$ ratio of the titanates caused by the replacement of $\mathrm{Na}^{+}$with $\mathrm{H}^{+}$during acid washing. With the washing $\mathrm{pH}$ lowered to 1.3 and 0.8 , the $24^{\circ}$ peak shifts to $25.2^{\circ}$. The peak at $25.2^{\circ}$ should correspond to the diffraction $(1,0,1)$ of anatase $\mathrm{TiO}_{2}$. And other crystal faces of anatase $\mathrm{TiO}_{2}$ can also be observed at the specific angles. The preceding results obtained with a progressive $\mathrm{pH}$ decrease have demonstrated a phase-transition sequence of Na-containing titanate, protonic titanate, and anatase $\mathrm{TiO}_{2}$. For the reason, the controlling of $\mathrm{pH}$ value during the acid rinsing process has an effect on the substituting degree of $\mathrm{Na}^{+}$ions with $\mathrm{H}^{+}$, structure, and crystal phase of products.

The variation of the specific surface area of $\mathrm{TiO}_{2}$ nanotubes with different washing $\mathrm{pH}$ values is described in Fig. 2 and Table I The $\mathrm{TiO}_{2}$ precursor synthesized by sol-gel method 
possesses the specific surface area of $151 \mathrm{~m}^{2} / \mathrm{g}$. The surface area of catalyst with rinsing $\mathrm{pH}$ of 6.5 slightly upgrades to $161.6 \mathrm{~m}^{2} / \mathrm{g}$ because of the shortage in $\mathrm{H}^{+}$ions. The amount of $\mathrm{H}^{+}$ions provided from acid rinsing may not be enough to replace the $\mathrm{Na}^{+}$, therefore the formation of catalytic powders are still lamellar structure not tubular. When the $\mathrm{pH}$ value of catalysts during the acid washing process was controlled to 2.2 further, the proportion of $\mathrm{Na}^{+}$ions within the titanate would be decreased due to the increasing of the washing acidity $\left(\mathrm{H}^{+}\right)$. The percent of the generated $\mathrm{TiO}_{2}$ nanotube would be also increased by scrolling the lamellar titanate or titanium oxide sheets into tubular structure. So the specific surface area can be up to $294.86 \mathrm{~m}^{2} / \mathrm{g}$.

TABLE I: SPeCIFIC Surface AREA, Porosity, AND Pore Size of THE COMMERCIAL $\mathrm{TIO}_{2}(\mathrm{P} 25)$, SELF-PREPARED ANATASE $\mathrm{TIO}_{2}$, AND THE SPECIMENS OBTAINED FROM HYDROTHERMAL NAOH TREATMENT ON $\mathrm{TIO}_{2}$ With SubSEQuent Post-TREATMEnt WASHING AT DifFERENT PH VALUES

\begin{tabular}{cccc}
\hline & $\begin{array}{c}\text { Surface area } \\
\left(\mathbf{m}^{\mathbf{2}} / \mathbf{g}\right)\end{array}$ & $\begin{array}{c}\text { Pore volume } \\
\left(\mathbf{c m}^{3} / \mathbf{g}\right)\end{array}$ & $\begin{array}{c}\text { Pore size } \\
(\mathbf{n m})\end{array}$ \\
\hline \hline $\begin{array}{c}\text { P25 } \\
\text { Self-prepared } \\
\text { TiOn }\end{array}$ & 52.103 & 0.132 & 10.117 \\
\hline $\begin{array}{c}\text { Photocatalyst } \\
\text { pH=6.5 }\end{array}$ & 150.98 & 0.165 & 4.369 \\
\hline $\begin{array}{c}\text { Photocatalyst } \\
\text { pH=2.2 }\end{array}$ & 294.86 & 0.173 & 4.281 \\
\hline $\begin{array}{c}\text { Photocatalyst } \\
\text { pH=1.3 }\end{array}$ & 381.20 & 0.242 & 3.279 \\
\hline $\begin{array}{c}\text { Photocatalyst } \\
\text { pH=0.8 }\end{array}$ & 335.13 & 0.358 & 3.761 \\
\hline \hline
\end{tabular}

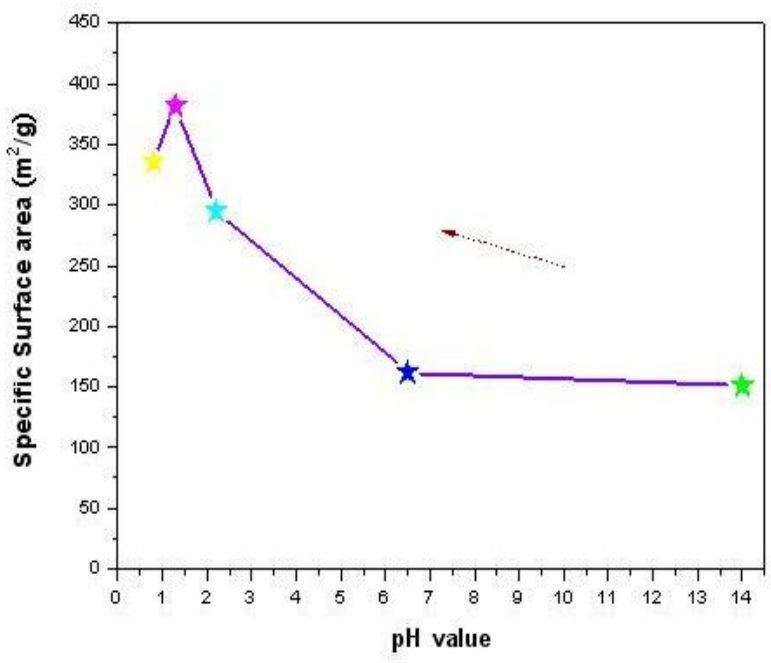

Fig. 2. Surface area of the specimens obtained from post-treatment washing at different $\mathrm{pH}$ values.

In the $\mathrm{pH}$-descending course, the area increases to reach a maximum of $381.2 \mathrm{~m}^{2} / \mathrm{g}$ at $\mathrm{pH}=1.3$, and it then decreases. At $\mathrm{pH}=1.3$, the aggregated nanotubes should be in a loose configuration, because the porosity was contributed to by the internal space as well as the interstice of the nanotubes. When we increased the acidity of the washing step to 0.8 , the nanotubes became defective because of the destruction of the acidity. So the area is reduced to $335.13 \mathrm{~m}^{2} / \mathrm{g}$ as well as the porosity. And also the surface area of the synthesized catalysts (titanate powder or $\mathrm{TiO}_{2}$ nanotube) are three to seven times larger than commercial $\mathrm{TiO}_{2}$ - P25 (25\% anatase, $75 \%$ rutile) powders.
The UV-VIS absorption spectra of $\mathrm{TiO}_{2}$ nanotube or titanate with different $\mathrm{pH}$ values of acid washing are shown in Fig. 3. The catalysts of titanate with acid rinsing $\mathrm{pH}$ of 6.5 have absorption in the UV region within $400 \mathrm{~nm}$, and it possesses the band gap about $3.31 \mathrm{eV}$. With the decreasing of acid rinsing $\mathrm{pH}$ value, the absorption range of photocatalysts will shift slightly to high wavelength. Comparing to these five curves, the absorption edge of $\mathrm{TiO}_{2}$ nanotubes with $\mathrm{pH}=1.3$ is observed at the widest wavelength range than others. And the band gap energy is the lowest of $3.12 \mathrm{eV}(\mathrm{pH}=4$ of catalyst with $3.28 \mathrm{eV}, \mathrm{pH}=2.2$ with $3.28 \mathrm{eV}$ ).

However, when the $\mathrm{pH}$ value of acid rinsing process is decreased to 0.8 , the absorption range of $\mathrm{TiO}_{2}$ nanotubes catalyst would shift back UV region. And the band gap energy becomes broad with $3.21 \mathrm{eV}$. It's because the $\mathrm{pH}$ value of acid washing is too low that the phenomenon of the defect and disintegration appeared in the structure of nanotubes by the destruction of acidity. At this point, its surface tension becomes larger, lattice distance becomes shorter, resulting in a increase of the vibrational frequency of bond in the nano-particles. Therefore, the absorption spectra will shift to high wavenumber (low wavelength). The experimental results indicate that anatase $\mathrm{TiO}_{2}$ nanotubes are produced as the $\mathrm{pH}$ value of acid washing is decreased to 1.3. It possesses the largest surface area, the widest absorption range, and may the best photocatalytic activity.



Fig. 3. UV-VIS dispersive reflectance spectra of photocatalysts obtained from post-treatment acid washing at $\mathrm{pH}$ value of (a) 6.5, (b) 4, (c) 2.2, (d) 1.3, (e) 0.8 .

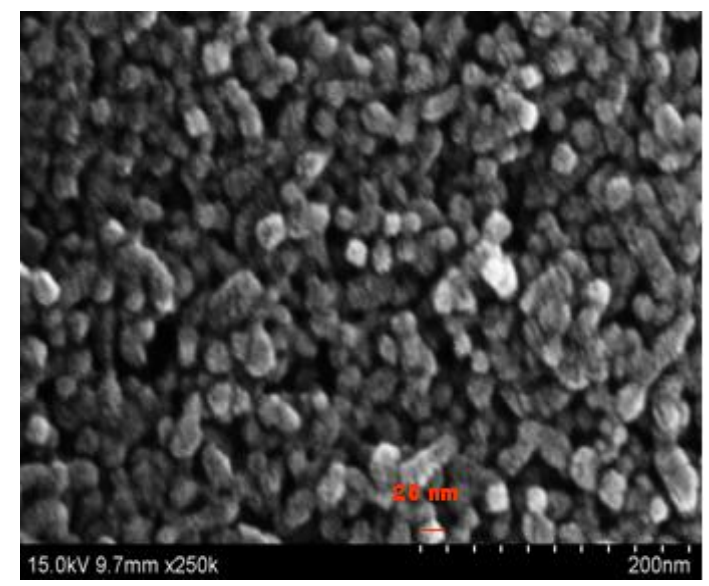

Fig. 4. SEM image of self-prepared anatase $\mathrm{TiO}_{2}$ powder via the sol-gel method. 

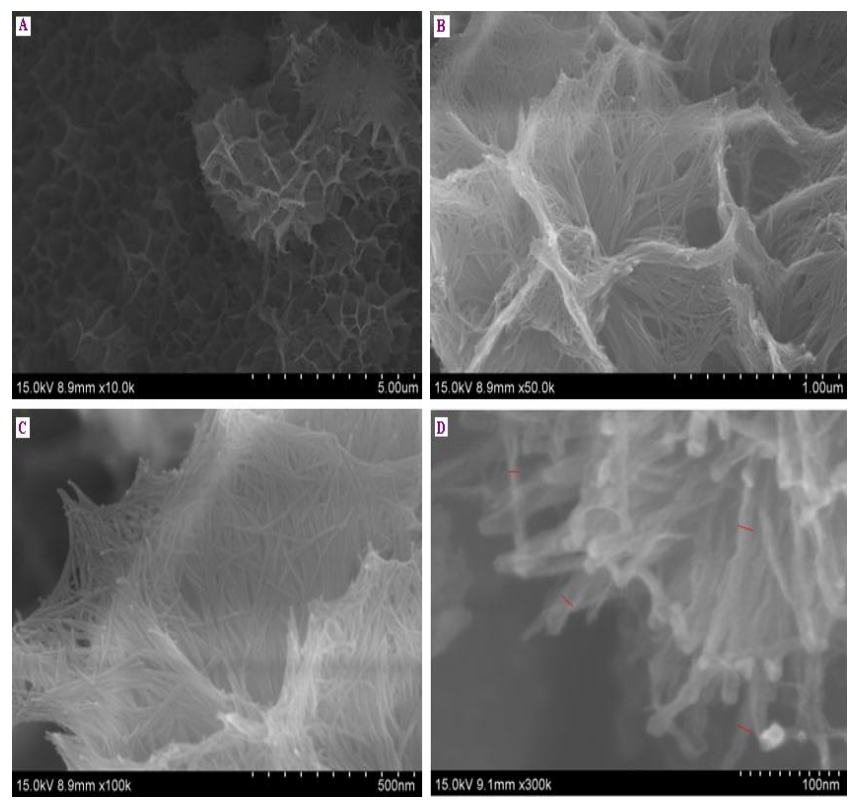

Fig. 5. The SEM image of $\mathrm{TiO}_{2}$ nanotube prepared from a $\mathrm{NaOH}$ treatment and with a subsequent acid washing of $\mathrm{pH}=1.3$. (A) Magnification of 10,000 times, (B) 50,000 times, (C) 100,000 times, (D) 300,000 times.

The SEM image of the $\mathrm{TiO}_{2}$ nanopowder obtained by sol-gel method with titanium ethoxide is shown in Fig.4. The morphology explains the uniform distribution of the particles, and its particle size is about $20 \mathrm{~nm}$. In this study, self-prepared anatase $\mathrm{TiO}_{2}$ powder is the precursor of the synthesized $\mathrm{TiO}_{2}$ nanotube.

The SEM images of the samples prepared from a concentrated $\mathrm{NaOH}$ treatment and with a subsequent acid washing of $\mathrm{pH}=1.3$ are shown in Fig. 5. Fig. $5 \mathrm{~A}$ is the microscopic figure with low-power field. We can observe that the uniformity of the structure distribution inside the catalysts is very excellent, and no particle is remained because of the incomplete reaction. As clearly seen from Fig. 5B and Fig. 5C, numerous fiberlike nanotubes grow from nano-size $\mathrm{TiO}_{2}$ particles. Its group is like a petal with bunchy arrangement not disarray. Under this condition, the outer diameter and length of the nanotubes is about $10 \mathrm{~nm}$ and $>1 \mu \mathrm{m}$ respectively from Fig. 5C and Fig. 5D. The $\mathrm{TiO}_{2}$ nanotubes made from nanopowders could improve significantly the specific surface area, increase the efficiency of electron transport and also separate the electron-hole pairs efficiently.

The photocatalytic activity is evaluated through the formation rate of $\mathrm{I}_{3}{ }^{-}$ions from the photocatalysis reaction of KI after illumination with UV light. By the definition, the higher concentration of $\mathrm{I}_{3}^{-}$ions, the better photocatalytic activity of photocatalyst. And the properties of those titanate or nanotube with different acid washing $\mathrm{pH}$ values are showed in Fig. 6. We can observe that the photocatalytic activity of titanate with the controlling $\mathrm{pH}$ value of 6.5 is obviously the lowest than others. With the decreasing of acid washing $\mathrm{pH}$ value, the nanotubes are produced gradually, and the photocatalytic activity becomes better. When the washing $\mathrm{pH}$ value of nanotubes is lower to 2.2 , the photocatalytic activity will be enhanced significantly. $\mathrm{TiO}_{2}$ nanotube synthesized with an acid washing treatment of $\mathrm{pH}=1.3$ possesses the best photocatalytic activity.

However, with the decreasing of $\mathrm{pH}$ to 0.8 further, it's seen clearly that the activity is lower than $\mathrm{pH}=1.3$. It's because the
$\mathrm{pH}$ value of acid washing is too low that the phenomenon of the defect and disintegration appeared in the structure of nanotubes by the destruction of acidity. The variation trend of photocatalytic acivity corresponds with the result of specific surface area. In summary, the clear anatase crystalline-phase of $\mathrm{TiO}_{2}$ nanotubes prepared with acid washing of $\mathrm{pH}=1.3$ can result in better efficiency of electron transport, the best porosity, and the largest specific surface area lead to the largest number of active sites which can participate in the reaction. The absorption edge is also observed at the widest wavelength range, $\mathrm{TiO}_{2}$ nanotubes with $\mathrm{pH}=1.3$ possesses the best photocatalytic activity among those samples.

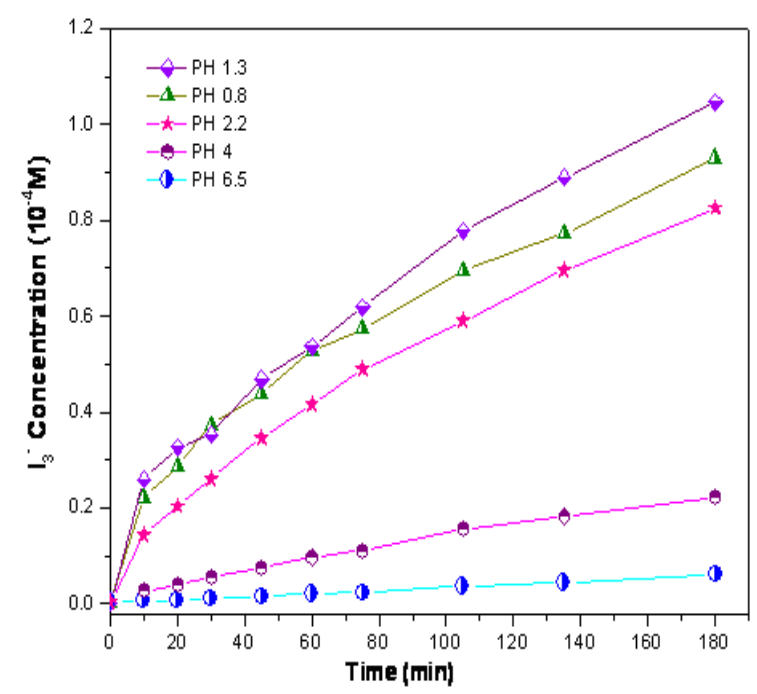

Fig. 6. The photocatalytic activities of photocatalysts evaluated through the formation rate of $\mathrm{I}_{3}{ }^{-}$ions from the photocatalysis reaction of KI after illumination.

\section{CONCLUSIONS}

In this study, nanosized $\mathrm{TiO}_{2}$ with tubular structure were synthesized and investigated. According to the hydrothermal treatment of anatase $\mathrm{TiO}_{2}$ with concentrated $\mathrm{NaOH}$ solution, layered or lamellar structures were formed in the present work. After being washed with $\mathrm{HCl}$, the lamellar phase will transform into titanate nanotubes with the gradual substitution of $\mathrm{Na}^{+}$with $\mathrm{H}^{+}$. This lamellar fragments, considered to be the intermediate phase for nanotubes formation, were mainly composed of $\mathrm{Na}_{2} \mathrm{Ti}_{2} \mathrm{O}_{5} \cdot 5 \mathrm{H}_{2} \mathrm{O}, \mathrm{Na}_{2} \mathrm{Ti}_{3} \mathrm{O}_{7}$ or lepidocrocite titanates. Then $\mathrm{TiO}_{2}$ nanotubes had been proved to be generated with acid washing $\mathrm{pH}$ value of 1.3 . When we increased the acidity of the washing step to 0.8 , the nanotubes become defective because of the formation of an anstase $\mathrm{TiO}_{2}$ phase (powder) on some spots of the tubes. They eventually transformed into nanocrystalline anatase with turbostratic stacking. For this reason, the controlling of $\mathrm{pH}$ value during the acid rinsing process has an effect on the substituting degree of $\mathrm{Na}^{+}$ions with $\mathrm{H}^{+}$, formation, crystalline structure, and even chemical composition of the final nanotube products.

As for the application of $\mathrm{TiO}_{2}$ nanotube, it has been used as the anode electrode of the dye-sensitized solar cell, and better cell efficiency and structure-related characteristics on the charge transport phenomenon have been reported [15]-[17]. 
Also some studies reported that $\mathrm{TiO}_{2}$ nanotube exhibits proton intercalation/de-intercalation and resultant photoelectrochromic properties [18], [19], anion doping to develop visible light responsible $\mathrm{TiO}_{2}$ nanotube for hydrogen generation from water splitting [20]-[23], and the photocatalytic degradation of organic pollutants using $\mathrm{TiO}_{2}$ nanotube photocatalysts [24], [25]. As mentioned before, one of the future research direction of the $\mathrm{TiO}_{2}$ nanotube may turn toward the application as the environmental and/or energy creating systems, which would become more important in the near future.

\section{ACKNOWLEDGMENT}

This research is financially supported by the National Science Council, Executive Yuan of Taiwan. And we appreciate the help of Institute of Nuclear Energy Research for the analysis instruments.

\section{REFERENCES}

[1] A. Fujishima and K. Honda, "Electrochemical photolysis of water at a semiconductor electrode," Nature, vol. 238, pp. 37-38, July 1972.

[2] J. Yang, Z. Jin, X. Wang, W. Li, J. Zhang, S. Zhang, X. Guo, and Z. Zhang, "Study on composition, structure and formation process of nanotube $\mathrm{Na}_{2} \mathrm{Ti}_{2} \mathrm{O}_{4}(\mathrm{OH})_{2}$ " Journal of the Chemical Society, Dalton Tanactions, issue 20, pp. 3898-3901, Sep. 2003.

[3] M. Zhang, Z. Jin, J. Zhang, X. Guo, J. Yang, W. Li, X. Wang, and Z. Zhang, "Effect of annealing temperature on morphology, structure and photocatalytic behavior of nanotubed $\mathrm{H}_{2} \mathrm{Ti}_{2} \mathrm{O}_{4}(\mathrm{OH})_{2}$, J Journal of Molecular Catalysis A: Chemical, vol. 217, pp. 203-210, Aug. 2004.

[4] A. Thorne, A. Kruth, D. Tunstall, J. T. S. Irvine, and W. Zhou, "Formation, structure, and stability of titanate nanotubes and their proton conductivity," The Journal of Physical Chemisty B, vol. 109, no. 12, pp. 5439-5444, Feb. 2005.

[5] A. Nakahira, W. Kato, M. Tamai, T. Isshiki, and K. Nishio, "Synthesis of nanotube from a layered $\mathrm{H}_{2} \mathrm{Ti}_{4} \mathrm{O}_{9} \cdot \mathrm{H}_{2} \mathrm{O}$ in a hydrothermal treatment using various titania sources," Journal of Material Science, vol. 39, pp. 4239-4245, July 2004.

[6] R. Ma, Y. Bando, and T. Sasaki, "Nanotubes of lepidocrocite titanates," Chemical Physics Letters, vol. 380, pp. 577-582, Oct. 2003.

[7] R. Ma, K. Fukuda, T. Sasaki, M. Osada, and Y. Bando, "Structural features of titanate nanotubes/nanobelts revealed by raman, X-ray absorption fine structure and electron diffraction characterizations," The Journal of Physical Chemisty B, vol. 109, no. 13, pp. 6210-6214, Apr. 2005.

[8] G. H. Du, Q. Chen, R. C. Che, Z. Y. Yuan, and L. M. Peng, "Preparation and structure analysis of titanium oxide nanotubes," Applied Physics Letters, vol. 79, no. 22, pp. 3702-3704, Sep. 2001.

[9] D. S. Seo, J. K. Lee, and H. Kim, "Preparation of nanotube-shaped $\mathrm{TiO}_{2}$ powder," Journal of Crystal Growth, vol. 229, pp. 428-432, July 2001.

[10] C. C. Tsai and H. Teng, "Regulation of the physical characteristics of titania nanotube aggregates synthesized from hydrothermal treatment," Chemistry of Materials, vol. 16, no. 22, pp. 4352-4358, Oct. 2004.

[11] T. Kasuga, M. Hiramatsu, A. Hoson, T. Sekino, and K. Niihara, "Titania nanotubes prepared by chemical processing," Advanced Materials, vol. 11, pp. 1307-1311, Oct. 1999

[12] C.-H. Lin and H.-L. Kuo, "The photocatalysis application of $\mathrm{TiO}_{2}-$ green production technology of hydrogen prepared from ethanol," Chemical Technology, vol. 158, pp. 185-192, Jan. 2006.

[13] Y. Q. Wang, G. Q. Hu, X. F. Duan, H. L. Sun, and Q. K. Xue, "Microstructure and formation mechanism of titanium dioxide nanotubes," Chemical Physics Letters, vol. 365, pp. 427-431, Nov. 2002.

[14] T. Kasuga, M. Hiramatsu, A. Hoson, T. Sekino, and K. Niihara, "Formation of titanium oxide nanotube," Langmuir, vol. 14, no. 12, pp 3160-3163, May 1998.

[15] Y. C. Liu, Y. F. Lu, Y. Z. Zeng, C. H. Liao, J. C. Chung, and T. Y. Wei, "Nanosturctured mesoporous titanium dioxide thin film prepared by sol-gel method for dye-sensitized solar cell," International Journal of Photoenergy, vol. 10, pp.1155-1164, April 2011.
[16] Y. Ohsaki, N. Masaki, T. Kitamura, Y. Wada, T. Okamoto, T. Sekino, K. Niihara, and S. Yanagida, "Dye-sensitized $\mathrm{TiO}_{2}$ nanotube solar cells: fabrication and electronic characterization," Physical Chemistry Chemical Physics, vol. 7, no. 24, pp. 4157-4163, Oct. 2005.

[17] P. L. Hung, M. H. Wen, K. H. Hung, J. S. Bow, H. W. Wang, J. C. C. Han, Y. F. Lu, J. C. Chung, Y. C. Liu, Y. Z. Zeng, and K. R. Ratinac, "3D electrodes for dye-sensitized solar cells: Synthesis of ITO nanowire arrays inside the $\mathrm{TiO}_{2}$ nanotubes," Journal of China Chemistry Scocity, vol. 57, 5A, pp. 1157-1161, Oct. 2010.

[18] U. O. Krasovec, M. Topic, A. Georq, and G. Drazic, "Preparation and characterisation of nano-structured $\mathrm{WO}_{3}-\mathrm{TiO}_{2}$ layers for photoelectrochromic devices," Journal of Sol-Gel Science and Technology, vol. 36, pp. 45-52, Oct. 2005.

[19] X. Chen and S. S. Mao, "Titanium dioxide nanomaterials: Synthesis, properties, modification, and applications," Chemical Review, vol. 107, no. 7, pp. 2891-2959, June 2007

[20] K. C. Sun, Y. C. Chen, M. Y. Kuo, H. W. Wang, Y. F. Lu, J. C. Chung, Y. C. Liu, and Y. Z. Zeng, "Synthesis and characterization of highly ordered $\mathrm{TiO}_{2}$ nanotube arrays for hydrogen generation via water splitting," Materials Chemistry and Physics, vol. 129, pp. 35-39, Sep. 2011.

[21] W. C. Lin, W. D. Yang, I. L. Huang, S. T. Wu, and Z. J. Chung, "Hydrogen production from methanol/water photocatalytic decomposition ssing $\mathrm{Pt} / \mathrm{TiO}_{2-\mathrm{x}} \mathrm{N}_{\mathrm{x}}$ catalyst," Energy and Fuels, vol. 23, pp. 2192, March 2009

[22] W. D. Yang, W. C. Lin, C. Yang, Z. J. Chung, and I. L. Huang, "Preparation and visible-light photocatalyst activity of nanometricsized $\mathrm{TiO}_{2-\mathrm{x}} \mathrm{N}_{\mathrm{y}}$ powders from a two-microemulsion process," Journal of Materials Research, vol. 24, no. 1, pp. 2574-2583, Aug. 2009.

[23] W. D. Yang, C. S. Hsieh, T. Y. Wei, Z. J. Chung, and I. L. Huang, "Synthesis and characterizations of nanometric-sized $\mathrm{TiO}_{2}$ powders as a photocatalyst for water splitting," Journal of Nanoscience and Nanotechnology, vol. 9, no.6, pp. 3843-3847, Jun. 2009.

[24] W. C. Lin, W. D. Yang, Z. J. Chung, and H. J. Chueng, "Preparation and application of titanate nanotubes on methylene blue degradation from aqueous media," in Proc. 2011 ICAMMM Conf., Applied Mechanics and Materials, vol. 117-119, pp. 786-789, Oct. 2012.

[25] W. C. Lin, R. Liu, W. D. Yang, Z. J. Chung, and H. J. Chueng, "Synthesis of titania nanotubes and its application on oxalic acid removal from aquatic environment," in Proc. ISCEMP 2011 Conf., Advanced Materials Research, vol. 391-392, pp. 1334-1337, 2012.

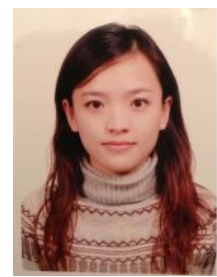

Yu-Zhen Zeng was born in Changhua County, Taiwan on March 31th, 1982. Ms. Zeng obtained a master's degree within two years from Nation Taiwan University of Science and Technology in Taipei city, Taiwan and chemical engineering was her major. The major field was the investigation of modified poly (vinyl alcohol) polymer electrolyte membrane for direct-methanol fuel cells. After graduation, she is engaged in scientific research as an assistant engineer immediately in Institute of Nuclear Energy Research, Atomic Energy Council of Taiwan. She has been working here for seven years. She investigated the electrode materials of the dye-sensitized solar cell, photocatalysts for hydrogen generation from water splitting, and photoelectrochromic devices. And she published the article of "Study of the Nanostructured Mesoporous Titanium Dioxide by Sol-Gel Method for Dye Sensitized Solar Cell" in Materials Research Society-Taiwan 2010 Annual Conference (MRS-T). Now her research fields are about the electrode materials of supercapacitor and shielding materials for high-energy electromagnetic radiation.



Yu-Chang Liu was born in Taichung City, Taiwan on July 10th, 1976. He completed a PhD degree in chemical and materials engineering from National Central University in Taoyuan County, Taiwan in 2005. And he studied on the preparation of amorphous nano-sized nickel alloy catalysts and its application for liquid phase selectivity p-chloronitrobenzene hydrogenation reaction during the doctoral research period. After graduation, he went in for the scientific research as an associate engineer in Institute of Nuclear Energy Research, Atomic Energy Council of Taiwan up to now. He investigated the electrode materials of the dye-sensitized solar cell, photocatalysts for hydrogen generation from water splitting, and photoelectrochromic devices. And he published the paper of 
"Nanosturctured mesoporous titanium dioxide thin film prepared by sol-gel method for dye-sensitized solar cell" in vol. 10 of Int. J Photoenergy in 2011. Now his interesting research fields are about high-energy electromagnetic radiation shielding materials and the energy storage system of vanadium redox battery.

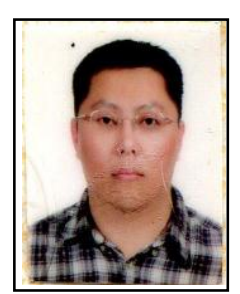

Yun-Fang Lu was born in Tainan County, Taiwan on November 3rd, 1973. He earned a doctor's degree in chemical and materials engineering from Chang Gung University in Taoyuan County, Taiwan in 2009. And he studied on the solute clustering during nucleation and crystal grown in a stirred solution and the operation and control for various crystallizers. At first he worked at USI Corporation as a RD engineer. Then he has gone in for the scientific research as an associate engineer in Institute of Nuclear Energy Research, Atomic Energy Council of Taiwan since 2004. He investigated the electrode materials of the dye-sensitized solar cell, photocatalysts for hydrogen generation from water splitting and photoelectrochromic devices in INER. And he published the article of "The electrochromic membrane of $\mathrm{WO}_{3}$ with $\mathrm{RF}$ magnetron sputter" in Materials Research Society-Taiwan 2010 Annual Conference (MRS-T). Dr. Liu, Ms. Zeng, and he are all the members of the same research team. So his research fields are the same as both two now.

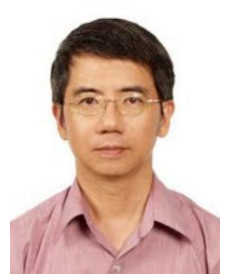

Jen-Chieh Chung was born in Tainan County of Taiwan on October 3rd, 1958. He completed a PhD degree in chemistry from National Tsing Hua University in Hsinchu City, Taiwan in 1997. And he studied on the decontamination of PCBs wastewater by radiolytic, electrochemical and microwave-Fenton technology during the doctoral research period.

$\mathrm{He}$ worked as a research assistant in Chung-Shen
Institute of Science and Technology, Armaments Bureau, M.N.D. during 1981-1986. Then he was employed as an assistant research fellow by Institute of Nuclear Energy Research, Atomic Energy Council of Taiwan during 1986-1990, associate research fellow during 1991-2000, and senior associate research fellow during 2001-2011. He has been employed under the position of senior research fellow and deputy head of chemical engineering division since 2012. His interesting research fields were hydrometallurgy, ceramic materials and the recovery of valuable metals during 1987-1990, chemical decontamination methods during 1991-1996, development of methods and procedures for soil decontamination during 1997-2003, the development of radioactive organic wastewater treatment technology during 2003-2005, the electrode materials of the dye-sensitized solar cell during 2005-2007, the preparation and technical development of colloidal decontamination solution during 2007-2010. And he has investigated the inorganic adsorbents applied in the radioactive wastewater treatments since 2011.He published the patents of "Method for making metal/titania pulp and photocatalyst" (Patent No. US 8,241,604, B2, Aug. 14, 2012) and "Wastewater treatment apparatus and method with stair-like heat treatment tanks" (Patent No. US 8,187,429 B2, May. 29, 2012). Dr. Chung has already devoted himself to scientific research for 33 years. 